\title{
Mass-Media Specificity of Building an Effective Narrative as a Strategic Communication Tool
}

\section{Мас-медійні особливості побудови ефективного наративу як інструмента стратегічних комунікацій}

Iryna Lysychkina

Ph.D. in Philology,

Associate Professor

\author{
Ірина Лисичкіна \\ кандидат філологічних наук, \\ доцент
}

\author{
E-mail: ilysychkina@,nangu.edu.ua \\ orcid.org/0000-0002-2050-9379 \\ Researcher ID: N-9873-2016
}

\author{
National Academy of the National \\ Guard of Ukraine \\ 3, Maidan Zakhysnykiv Ukrainy, \\ Kharkiv, Ukraine, 61001
}

Національна академія

Національної гвардї України

$\triangle$ майдан Захисників України, 3,

Харків, Україна, 61001

Original manuscript received August 29, 2018

Revised manuscript accepted September 25, 2019

\begin{abstract}
Objective. This research aims at defining the principles of constructing effective narratives with the use of the strategic communication capabilities and the media.

Materials and Methods. Publications in modern English and Ukrainian mass-media have been analyzed using methods and techniques of discourse analysis, contentand intent-analysis with elements of pragmatic and narrative analysis. The author's methodology included the following: to identify the author's intention and motives, the main topoi and points of the narrative focalization, to define hidden beliefs, social and psychological basis for the recipient's perception of the narrative, to outline effective strategies for the narrative construction and dissemination in the media.

Results. In general, modern media have the capacity of constructing the desired frames in the audience's consciousness by creating a mental model of the situation, on which the consumer of the information starts to rely. Decision-making now is reliant
\end{abstract}


on the media consciousness, a virtual world imposed by the media and constructed with the help of relevant narratives. Modern strategic narratives usually have the external focalization which gets more credibility when supported and presented by the focalization points of celebrities and experts. Competing narratives, as well as the plurality of possible interpretations of events, are destroyed with the help of the media, which begin to broadcast one interpretation of the event that matches the narrative, by this making it the truth. Simultaneous use of several different media intensifies the influence and support the narrative. Repeating information changes its status and makes it not just a fact, but general knowledge. Any narrative is not only a sequential story of the selected events, but also persuasion in its nature. Persuasion is enhanced when narratives resonate with the audience's value system.

Conclusions. As a strategic communication tool, an effective narrative is constructed with regard to all the aspects of communication, psycholinguistic and social aspects being especially important. Further insights into the problem of shaping narratives will allow outlining best practices and their elements to develop image-forming narratives.

Key words: strategic communication, narrative, media-consciousness, frame, mass-media.

\section{Вступ}

Аналіз інформаційного простору, у якому існує сучасна людина, свідчить, що «доступу до інформації недостатньо, потрібна система iï розуміння» (Chomsky, 2008). Значущими у цьому сенсі постають сучасні розвідки з психолінгвістики, зокрема пов'язані з урахуванням перспективи в референційній комунікації (Damen, Wijst, Amelsvoort \& Krahmer, 2018), імпліцитного знання (Suzuki, 2017), довіри до інформації та мовця (Clementson, 2018) тощо. Людина сприймає інформацію крізь призму власної системи цінностей, свого досвіду та уявлень про світ, у результаті чого розуміння інформації може суттєво відрізнятися від інтенції автора. Стратегічні комунікації покликані нівелювати або зменшити такі розбіжності шляхом удосконаленого використання наративу як основного інструмента, що не можливо без звернення до психолінгвістичного аспекту побудови та функціонування наративу в інформаційному просторі.

Зауважимо, що попри широку популярність та часте зловживання, «стратегічні комунікації» $є$ відносно новим терміном, що визначає «практику навмисного та цілеспрямованого 
Мас-медійні особливості побудови ефективного наративу...

спілкування, яке комунікатор впроваджує в публічній сфері від імені суб'єкта комунікації для досягнення поставлених цілей» (Holtzhausen \& Zerfass, 2015: 74).

Стратегічні комунікації задіюють широкий спектр стратегій впливу, спеціально розроблених для кожної цільової аудиторії, причому цільова аудиторія обумовлює вибір каналів впливу стратегічних комунікацій: від веб-сайтів та медіа-повідомлень для широкої аудиторії до Twitter та Facebook для молодого покоління. Хоча роль мас-медіа для стратегічних комунікацій важко переоцінити, традиційні (старі) мас-медіа користуються меншою довірою. Потенціал нових медіа (соціальні мережі, сервіси блогосфери тощо) є дуже високим: «Війна дискурсів, інтенсифікація й технологічне конструювання дискурсу, «битва наративів» - усі ці комунікативні події відбуваються в нових медіа і формують соціально-політичну реальність» (Компанцева, 2018: 121). Стратегічні комунікації спрямовані на формування та підтримання позитивного іміджу/репутації суб'єкта комунікації, таким чином заповнює інформаційний простір відповідною інформацією та зменшує вплив небажаної дискредитаційної інформації 3 інших джерел.

Для комунікатора існує кілька основних принципів стратегічних комунікацій: здорові професійні зв'язки з мас-медіа, визнання різноманітності мас-медіа та вибору відповідних засобів масової інформації як каналу зв’язку, відповідність кожного повідомлення загальному наративу комунікативного суб'єкта. Стратегічні комунікації оперують фактичною інформацією, i таким чином відмежовуються від пропаганди 3 ïi методами «Великої брехні». Стратегіï обману та маніпулювання вимагають особливої обережності при їх використанні, оскільки вони можуть призвести до втрати довіри до комунікатора та об’єкта комунікації у той час, як «підтримання довіри вимагає, щоб діла відповідали словам» (Sillanpää, 2015).

Для стратегічних комунікацій важливим простором $є$ масмедіа, які мають здатність конструювати бажані фрейми в свідомості аудиторії. У своїй теорії фреймів Дж. Лакофф стверджує, що «фрейми є ментальними конструктами, які формують спосіб бачення світу» (Lakoff, 2014: XV), отже «фреймування є критично важливим, оскільки фрейм, який встановлюється в свідомості 
читача (або слухача, глядача тощо), майже неминуче веде цю людину до висновку, бажаного автором, і це блокує розгляд інших можливих фактів та тлумачень» (Lakoff, 2014: XV).

Фрейми будуються через створений мас-медіа віртуальний світ, який, зазвичай яскравіший, ніж справжній, чітко спирається на когнітивну карту людської свідомості. Ця віртуальна ментальна модель формує ще один «варіант» світу, який накладається на основну ментальну модель. Мас-медіа професійно враховують болісні точки масової свідомості для побудови комунікації, тому наразі пересічні адресати не можуть розрізняти фейки від істини, оскільки мають справу 3 великою кількістю фейкових новин та фальсифікацій. «Fake news» (фальшиві новини) оголошено «Словом року - 2017» за версією Collins, причому використання цього терміну зросло на 365\% з 2016 року (Collins, 2017).

У 80-х роках минулого століття Н. Хомський стверджував, що «засоби масової комунікації США $є$ ефективними та могутніми ідеологічними інституціями, які здійснюють системну підтримку пропагандистської функції, спираючись на ринкові сили, інтернаціоналізовані припущення та самоцензуру, без відкритого примусу за допомогою пропагандистської моделі спілкування» (Herman \& Chomsky, 1988). Сьогодні ми маємо справу із політизацією мас-медіа та відповідною політизацією розуму аудиторії. «Медіа-свідомість можна розглядати як друге «Я» людини, що суттєво формує іï думки та поведінку» (Почепцов, 2017a). У більшості випадків людина не конфліктує 3 моделлю світу, не шукає альтернативної інтерпретації. Коли тлумачення в розумі співпадає з тим, що пропонується в мас-медіа, ця модель зміцнюється. Вбудовані фрейми підтримують цей процес i блокують будь-яку «сторонню» інформацію. Подальші «сторонні» факти відхиляються людиною, якщо вони не відповідають існуючій моделі ситуації. Соціальні медіа, у свою чергу, мають можливість оцінювати власний вплив і чітко розуміти свою аудиторію, оскільки «вони можуть виміряти, як ви реагуєте, вони знають, як потрапити під шкіру» (Do social media, 2017).

Таким чином, медіа-свідомість є фактично віртуальним світом, нав'язаним мас-медіа. Мас-медіа здатні спроектувати світ, відмінний від реальності, і підмінити реальність віртуальністю, яка сприймається як реальність, оскільки пересічний адресат не 
Мас-медійні особливості побудови ефективного наративу...

має ані волі, ані часу, ані можливості перевірити це, а прискорена зміна новин позбавляє людину адекватного розуміння. Цей віртуальний світ побудований за допомогою відповідних наративів, які розробляються власне мас-медіа (а не зацікавленими особами) або в межах стратегічних комунікацій суб’єкта комунікації, а потім широко транслюються через мас-медіа. Наративи постають зброєю в гібридних війнах, оскільки здатні конструювати бажану реальність.

Наратив є міждисциплінарним поняттям, яким оперують історики, політологи, соціологи, психологи, філологи тощо. Грунтовний аналіз наративу має міждисциплінарний характер i передбачає звернення до положень соціального конструктивізму (Kratochwil, 1993; Hopf, 2002; Zehfuss, 2002), комунікативної лінгвістики (Атаян, 1981; Бацевич, 2004), лінгвістичної прагматики (Почепцов 2013; Grice, 1989; Ostin, 1962; Searle, 1998), соціолінгвістики (Bucholtz \& Hall, 2008; Wardhaugh, 2010; Lakoff, 2014), когнітивної лінгвістики (Fillmore, 1982; Кубрякова, 2004), дискурсних дослідженнях (Dijk, 1995; Карасик, 2002; Селиванова, 2002; Макаров, 2003), медиалінгвістики (Добросклонська, 2014; Bell, 1995) тощо.

У широкому сенсі під наративом розуміється «історія, яка пояснює дії суб’єкта для їх виправдовування перед певною аудиторією» (Denzin, 1989). Наратив передбачає структурування події (Ovchinnikova, 2018), постає історією послідовності подій, що мають значення для наратора та аудиторіï (Denzin, 1989), отже, він містить історії про події, визначені наратором / комунікатором як актуальні для аудиторії. Іншими словами, «для того, щоб бути ефективними, наративи повинні як резонувати з основними цінностями аудиторії, так i виправдовувати переконливий опис причинно-наслідкових зв'язків, що об'єднує події разом в пояснювальній основі» (Antoniades, O’Loughlin \& Miskimmon, 2010: 5). Зазвичай, наратив складається 3 основного (вихідного) тексту (повідомлення) та семантично пов'язаних додаткових повідомлень. Наратив постає систематизованим гіпертекстом, об'єднаним певною подією/подіями або метою. Актуальним залишається встановлення механізму формування та розповсюдження стратегічних наративів засобами стратегічних комунікацій та мас-медіа. 
Це дослідження спрямоване на визначення принципів побудови ефективних наративів з використанням можливостей стратегічних комунікацій та мас-медіа.

Об'єктом дослідження є сучасний мас-медіа дискурс США, Великобританії та України, а саме повідомлення суспільнополітичної тематики новинного та аналітичного типів. Матеріалом дослідження слугували публікації в «The Guardian», «The Economist», «Time», «Українська правда», а також новини та аналітичні передачі на каналах «BBC», «CNN» та «1+1», а також повідомлення на офіційних сайтах силових структур (ngu.gov.ua, calguard.ca.gov.).

\section{Методи та методики дослідження}

Для досягнення поставленої мети використовувався інструментарій методів і прийомів дискурс-аналізу (опис й характеристика мовленнєвого спілкування «людина - мас-медіа», зокрема психологічного аспекту цієї взаємодії, а також контентта інтент-аналіз публікацій та скриптів відео повідомлень для вияву прихованих переконань, соціальної та психологічної зумовленості сприйняття адресатом інформації), прагматичного та конверсаційного аналізу (для визначення перформативної природи соціальної реальності й мови). Використаний герменевтичний підхід до розуміння текстів дозволив розкрити їхні імпліцитні смисли. Методики наративного аналізу дозволили визначити глибинні структури аналізованих текстів і їхню вербалізацію у поверхневих структурах дискурсу. Елементи контекстуально-інтерпретаційного методу послуговували для встановлення статусу тексту відносно інших текстів, авторського задуму та мотивів, а також для розуміння адресної спрямованості тексту.

Авторська методика аналізу корпусу дослідження для встановлення принципів побудови наративів передбачала:

1) вияв авторського задуму та мотивів;

2) окреслення основних топосів та концептів;

3) встановлення основних імплікатур та їхньої кореляції 3 базовими концептами;

4) визначення точки фокусування; 
Мас-медійні особливості побудови ефективного наративу...

5) проектування соціальної та психологічної зумовленості сприйняття наративу адресатом;

6) окреслення ефективних стратегій побудови та поширення наративу в мас-медіа.

\section{Результати та дискусії}

Стратегічні наративи силових структур покликані допомогти адресатові краще зрозуміти події, за яких використовувалася сила, таким чином, щоб паралельно сформувалося певне бажане ставлення до події. Використання топосів корисності для суспільства, безпеки, урахування потреб суспільства сприяє реалізації імплікатури незамінності й безальтернативності силових структур для забезпечення безпеки суспільства.

Наративи формуються 3 урахуванням культурного контексту адресата, оскільки спираються на традиції, міфи та історичну пам'ять аудиторії, причому наративи здатні одночасно їх змінювати, спростовувати та створювати нові.

За словами Ж. Женета (Genette, 1930), будь-яка історія має точку зору, яка співвідноситься з одним із персонажів чи голосів у наративі. Це точка фокусування наративу, і вона може змінюватися протягом наративу. Сучасні стратегічні наративи, які транслюються через мас-медіа та впливають на свідомість аудиторії, як правило, мають зовнішне фокусування, тобто наративна точка зору не пов'язана $з$ жодною дійовою особою, хоча це зовнішнє фокусування отримує більшу довіру, коли підтримується та представляється точками фокусування видатних людей та експертів. У різних політичних ток-шоу, особливо під час виборчих кампаній, беруть участь так звані коментатори (відомі люди, експерти тощо), які часто не мають нічого спільного 3 обговорюваними питаннями, але вони є авторитетами у своїх сферах, яким аудиторія довіряє, оскільки відчуває, що вони знають знаменитостей як членів сім'ї, позаяк слідкує за ними в мас-медіа та соціальних мережах, або вірить, що мас-медіа запрошують дійсно кваліфікованих експертів, щоб поділитися своєю неупередженою точкою зору. Дотично зауважити, що краще сприймаються аудиторією експерти, орієнтовані на консенсус, які займають двосторонню позицію, щоб 
їм більше довіряли (Mayweg-Paus \& Jucks, 2018). Вибір правильної точки фокусування є значущим, оскільки це дозволяє заблокувати критичне мислення аудиторії та забезпечити поширювану інформацію з перебільшеним статусом знання. Це цілком зрозуміла боротьба з чужою позицією/точкою зору, оскільки знання є вищими за інформацією (Sillanpää, 2015).

Інформація формує модель світу в свідомості, де в принципі не може бути жодних конкуруючих між собою інтерпретацій. Люди приймають ту чи іншу точку зору, щоб уникнути пізнавального дисонансу. Фрейми в свідомості аудиторії дозволяють відфільтрувати будь-які факти, які суперечать стратегічному наративу. При цьому стратегічний наратив здатний руйнувати або дискредитувати конкуруючі наративи, використовуючи серед інших семантичні ходи реверсування понять та зміни фокусу повідомлень.

Конкуруючі наративи, а також численні можливі тлумачення подій, знищуються за допомогою мас-медіа, які починають транслювати певну інтерпретацію подій відповідно до наративу, i таким чином ця інтерпретація стає істиною. Одночасне використання декількох різних мас-медіа інтенсифікує вплив і підтримує наратив. Повторювана інформація змінює свій статус і стає не просто фактом, а загальними знаннями. Наприклад, у виборчій кампанії 1993 року Руді Джуліані уникав вживання слів «crime», «criminals» та пов'язаної з ними «fighting crime», і надавав перевагу «personal and public safety» та «safe, civil society» (Luntz, 2007: 178). Зміна сприйняття є важливим аспектом стратегічного наративу.

Успіх будь-якого наративу залежить від вибору основних концептів для цього наративу та їх конкретної вербалізації у різних контекстах для різних аудиторій. Наприклад, наратив про реформи повинен містити концепти «успіх», «покращення», «краще життя», «перспективи», «перехідні виклики», «майбутнє», «добробут». Наратив «Примирення» може вимагати «майбутнього», «перспектив», «компромісу», «ичивілізованого сусідства», «сnівпращі»», «розвитку» тощо. Аналізуючи сучасну ситуацію в Україні, Г. Почепцов вважає, що зміна наративу «Зрада» на «Успіх» $\epsilon$ важливою для місцевого населення, а також для наративу «Успіх» для зовнішньої аудиторії (Почепцов, 2017b).

3 позицій прагматики, фактор адресата $є$ найбільш значущим для успішності наративу, оскільки «важливо не те, що ви говорите, це те, що люди чують» (Luntz, 2007). 
Мас-медійні особливості побудови ефективного наративу...

Таким чином, наратив будується 3 урахуванням цільової аудиторії: вік, стать, освіта, професія, життєвий досвід, припущення тощо. Навіть риторичні навички нині не стосуються мови, вони стосуються визнання соціальних обставин і розуміння очікувань аудиторії (Krebs, 2015). Наприклад, жінки, як правило, краще реагують на історії, анекдоти та метафори, а чоловіки більше орієнтовані на конкретні факти та статистичні дані, молоді люди менше читають і спілкуються через Tweeter.

Ідеальний наратив повинен донести до аудиторії певне особисте значення і цінності. У цьому сенсі в наративах силових структур широко використовується семантична категорія «своє коло», яка передбачає виокремлення «своїх» та «чужих» та дискримінацію «чужих», наприклад: We are the nation's first line of defense. We accomplish what others cannot accomplish and go where others cannot go (Central, 2018).

Апеляція до цінностей передбачає звернення до цінностей структури (Service), нації (Integrity, Quiet Patriotism) та суспільства (Excellence, The Truth), як-то: We put Country first and Agency before self. Quiet patriotism is our hallmark. We seek and speak the truth. We hold ourselves - and each other - to the highest standards (Central, 2018).

Персоналізація та гуманізація повідомлення (у межах наративу) допомагають викликати емоційну пам'ять (Luntz, 2007). Так, на офіційному сайті Національної Гвардії США подається узагальнений образ гвардійця «I am the Guard»: Civilian in Peace, Soldier in War ... of security and honor for three centuries I have been the custodian ... I am the Guard! (I am the Guard, 2018). У кількох рядках викладений персоніфікований історичний наратив цієї силової структури: Through the jungles and on the beaches I fought the enemy... beat, battered, and broke him. I scrambled over Normandy's beaches - I was there! I flew MiG Alley to the Yalu - I am the Guard! I fought in the skies above Vietnam - I was there! In the skies and on the ground, I made the Arabian desert feel the fury of the storm (I am the Guard, 2018).

Взагалі, враження від наративу можна було б зобразити як супер додаткові смисли: історії додані до історій, факти до фактів. Таким чином вони ще більше зміцнюють фрейми у свідомості аудиторії та «обробляють» ці події. 
Будь-який наратив $є$ не лише історією послідовності вибраних подій, а й переконанням за своєю сутністю. Для того, щоб наратив був переконливим, особливу увагу слід приділяти структурі повідомлень у цьому наративі, яка залежить від багатьох факторів: аудиторії, каналу, часу, теми тощо.

Доведено ефективність «дати контекст чому раніше, ніж щ̧о з того та як», оскільки порядок представлення інформації визначає контекст, і це може бути важливим як суть самої інформації. Це відповідає важливому мовному правилу, яке суперечить логіці: «А + $\mathrm{B}+\mathrm{C}$ не обов'язково дорівнює $\mathrm{C}+\mathrm{B}+\mathrm{A} »$ (Luntz, 2007).

Побудовані як частина стратегічних комунікацій, а потім поширювані через мас-медіа сильні наративи блокують критичні роздуми аудиторії про ситуацію, оскільки вони наполегливо надають аудиторії достатню інформацію та інтерпретацію фактів, які, як правило, перетворюються на знання, перекладене мовою аудиторії та обговорюване авторитетними відомими людьми та експертами.

Наративи іміджеформувального характеру як викладення певних подій, пов'язаних із діяльністю конкретної організації, наприклад силової структури, мають тенденцію висвітлювати події, які сприяють формуванню позитивного іміджу, та замовчувати або окреслювати в загальних словах події та дії дискредитаційного характеру.

Для таких наративів особливого значення набуває концептуальна основа, загальна для всіх повідомлень, що складають наратив. Спланована акцентуація базових концептів через ключові слова й певні інформативні кванти, які несуть більше смислове навантаження в повідомленнях, сприяє виникненню в адресата емоційного резонансу.

Так, іміджеформувальний наратив силової структури формується низкою різноманітних повідомлень з однієї тематики для різних контекстів та різних адресатів замість одного універсального інваріантного повідомлення. Однак, такі повідомлення $\epsilon$ узгодженими, когерентними й підсилюють одне одного.

Оскільки сучасна людина більше орієнтується на візуальне сприйняття інформації, мас-медіа повідомлення про силову структуру мають супроводжуватися фото та/або відеорядом. Обсяг інформації має бути малим, враховуючи той факт, що 
Мас-медійні особливості побудови ефективного наративу...

довгі повідомлення $є$ важкими, їх часто не читають, виходячи лише $з$ обсягу.

Для того, щоб наративу в цілому довіряли, сама структура має повідомляти про негативні події, пов’язані 3 діяльністю цієї структури. Замовчувати певну інформацію $\epsilon$ доцільним, однак, надання недостовірної, або неправдивої інформації навпаки призведе до ще більшої дискредитації. Зазвичай, повідомлення, у яких йдеться про неприємні події, мають будуватися за схемою «сендвіч»: позитив - негатив - позитив, а саме: позитивний факт про структуру - негативна інформація, через яку власне й створюється таке повідомлення, - позитивна інформація (важливість їхньої діяльності в цілому, аналогії із попередніми подіями, вказівка про вжиті заходи, недопустимість повторення таких подій в майбутньому тощо). Вчасно надана в достатньому обсязі інформація дозволяє запобігти появі низки запитань та неправильних суджень щодо наративу структури взагалі. Отже, ефективним є переобтяження інформацією й перекручування фактів. Важливими характеристиками дискурсу стратегічних комунікацій є візуалізація та метафоризація.

Основними семантичними умовами формування іміджеформувального наративу силової структури є аргументованість інформації, яка досягається шляхом посилання на авторитети, наведення фактуальної інформації (статистичних даних, історичних фактів тощо), та позитивна емотивність, яка досягається серед іншого високою апелятивністю, впливом на емоційному підгрунті, нав'язуванням «власних» переконань, залученням риторичних технік та кшталт «свій - чужий» тощо. Інформативна та спонукальна комунікативні стратегії постають домінувальними в цьому контексті.

Наративу властива процесуальність, оскільки процес формування наративу може бути тривалим i характеризується потенційною зміною точки фокусування у відповідності до змін інтересів наратора.

Іміджеформувальний наратив силової структури характеризується ретельним плануванням, значним впливом екстралінгвістичних чинників, фреймовою будовою взаємопов'язаних повідомлень, у яких вербалізуються основні концепти, пов'язані із системою цінностей адресата та загальноприйнятими цінностями суспільства. 


\section{Висновки}

Поточні зміни в інформаційному просторі впливають на те, як люди шукають та знаходять інформацію, впливають на тип інформації, отримувану людьми, зменшують значення міжособистісного спілкування, переглядають масштаб інформації та роль соціальних мереж. Інформаційні технології спростили навантаження на пам'ять людини і навіть розум, тим самим, стали більш відеотехнологічними, ніж інформаційним. Масова свідомість була замінена медійною свідомістю 3 домінувальною роллю телевізійних серіалів та ток-шоу, які диктують аудиторії моделі поведінки.

Враховуючи наявні можливості стратегічних комунікацій та мас-медіа для конструювання бажаних фреймів у свідомості аудиторії, а також глобальної експансії мас-медіа та їх зростаючого впливу на аудиторію, особливої значущості набувають фрейми, побудовані переважно засобами масової інформації. Оскільки ці фрейми здатні відфільтрувати вхідну інформацію, необхідною постає корекція існуючих фреймів та конструювання нових, які не заблокують бажаний наратив.

Наратив $є$ гіпертекстом будь-якого жанру та будь-якої функціональності. Діалогічний характер наративу активує інтертекстуальні зв'язки як між повідомленнями в межах наративу, так і між наративами. Стратегічні наративи постають інструментом цілеспрямованої презентації та поширення наратором свого вкладення подій 3 урахуванням власних інтересів. Наративи як історії послідовностей значущих для наратора подій апелюють до цінностей адресата задля забезпечення більшої переконливості історій. Сучасним стратегічним наративам властива емотивність передбачувана, усвідомлювана властивість мовлення, пов'язана 3 використанням мовних засобів, які цілеспрямовано надають наративу емоційності для впливу на адресата.

Таким чином, ефективний наратив будується 3 урахуванням усіх аспектів комунікації, причому психолінгвістичний та соціальний аспекти постають найбільш важливими. Психолінгвістичний інструментарій аналізу наративу доречно використовувати для формування бажаних та аналізу існуючих стратегічних наративів 
Мас-медійні особливості побудови ефективного наративу...

у мас-медійному просторі. Подальше розуміння проблеми формування наративу дозволить висвітлити найкращі практики та ïx елементи для розробки актуальних наративів, зокрема наративів іміджеформувального характеру.

\section{Література}

Атаян, Э.Р. (1981). Коммуникация и раскрытие потенций языкового знака. Ереван: ЕреванГУ.

Бацевич, Ф.С. (2004). Пролегомены к теории коммуникативного смысла. Культура народов Причерноморья, 49(1), 77-79.

Добросклонская, Т.Г. (2014). Массмедийный дискурс как объект научного исследования. Научные ведомости Белгородского государственного университета, 13(184), Вып. 22, 181-187.

Карасик, В.И. (2002). Языковой круг: личность, концепты, дискурс. Волгоград: Перемена.

Компанцева, Л.Ф. (2018). Психолінгвістичний опис технологічного дискурсу нових медіа. Psycholinguistics. Психолінгвістика. Психолингвистика, 23(2), 120-131. http://doi.org/10.5281/zenodo.1208639

Кубрякова, Е.С. (2004). Об установках когнитивной науки и актуальных проблемах когнитивной лингвистики. Вопросы когнитивной лингвистики, 1, 6-17.

Макаров, М.Л. (2003). Основы теории дискурса. Москва: ИТДГК «Гнозис».

Почепцов, Г.Г. (2013). Избранные труды по лингвистике. Винница: Нова Книга.

Почепцов, Г.Г. (2017а). Медиасознание: как найти черную кошку в темной комнате. RELGA, 12(330). Retrieved from http://www.relga.ru/Environ/ WebObjects/tgu-www.woa/wa/Main?textid=5147\&level1=main\&level2=articles (Дата обращения 07.05.2019).

Почепцов, Г.Г. (2017b). Доктор філологічних наук Георгій Почепцов: «Дуже важливо змінити наратив «зрада» на «успіх». Урядовий кур'єр. 13.10.2017. Retrieved from https://ukurier.gov.ua/uk/articles/doktor-filologichnih-nauk-georgijpochepcov-duzhe-/ (Дата звернення 07.05.2019).

Селиванова, Е.А. (2002). Основь лингвистической теории текста и коммуникации. Киев: ЦУЛ, Фитосоциоцентр.

Antoniades, A., O’Loughlin, B., \& Miskimmon, A. (2010). Great Power Politics and Strategic Narratives. Working Paper, 7, The Centre for Global Political Economy, University of Sussex. https://doi.org/10.4324/9781315770734

Bell, A. (1995). Language and the Media. Annual Review of Applied Linguistics, 15, 23-41. https://doi.org/10.1017/S0267190500002592

Bucholtz, M., \& Hall, K. (2008). All of the Above: New Coalitions in Sociocultural Linguistics. Journal of Sociolinguistics, 12(4), 401-431. https://doi.org/10.1111/ j.1467-9841.2008.00382.x

Chomsky, N. (2008). Talks at Google. Retrieved May 2, 2008. Retrieved from https:// www.youtube.com/watch? $\mathrm{v}=\mathrm{rnLWSC} 5 \mathrm{p} 1 \mathrm{XE} \# \mathrm{t}=27 \mathrm{~m} 38 \mathrm{~s}$

Clementson, D.E. (2018). Effects of Dodging Questions: How Politicians Escape Deception Detection and How They Get Caught. Journal of Language and Social Psychology, 37(1), 93-113. https://doi.org/10.1177/0261927X17706960 
Collins. (2017). 2017 Word of the Year Shortlist. Retrieved from https://www. collinsdictionary.com/word-lovers-blog/new/collins-2017-word-of-the-yearshortlist,396,HCB.html

Damen, D., Wijst, P., Amelsvoort, M., \& Krahmer, E. (2018). Perspective-Taking in Referential Communication: Does Stimulated Attention to Addressees' Perspective Influence Speakers' Reference Production? Journal of Psycholinguistic Research, 48, 257-288. https://doi.org/10.1007/s10936-018-9602-7

Denzin, N.K. (1989). Interpretive Biography. Newbury Park, California, London: Sage. https://doi.org/10.4135/9781412984584

Dijk, T.A., van. (1995). On Macrostructures, Mental Models, and other Inventions: A brief personal history of the Kintsch-van Dijk theory. Discourse Comprehension: Essays in Honor of Walter Kintsch (pp. 383-410). London: Hillsdale.

Do Social Media Threaten Democracy? (2017). The Economist. Retrieved November 4. Retrieved from https:/www.economist.com/news/leaders/21730871-facebookgoogle-and-twitter-were-supposed-save-politics-good-information-drove-out

Fillmore, Ch.J. (1982). Frame Semantics. Linguistics in the Morning Calm (pp. 111137). Seoul: Hanshin Publishing Co.

Genette, G. (1930). Narrative Discourse. An Essay in Method. Ithaca, New York: Cornell University Press.

Grice, H.P. (1989). Studies in the Way of Words. Harvard: Harvard University Press.

Herman, E.S., \& Chomsky, N. (1988). Manufacturing Consent: The Political Economy of the Mass Media. New York: Pantheon Books.

Hopf, T. (2002). Social Construction of International Politics: Identities \& Foreign Policies. Cornell: Cornell University Press.

Holtzhausen, D., \& Zerfass, A. (2015). Strategic Communication: Opportunitities and Challenges of the Research Area. In D. Holtzhausen \& A. Zerfass (Eds.), The Routledge Handbook of Strategic Communication (pp. 3-17). New York, London: Routledge, Taylor and Francis Group. https://doi. org/10.4324/9780203094440

Kratochwil, F. (1993). The Embarrassment of Changes: Neo-Realism as the Science of Realpolitik without Politics. Review of International Studies, 19, 1-18. https:// doi.org/10.1017/S0260210500117346

Krebs, R.R. (2015). Narrative and the Making of US National Security. New York: Cambridge University Press. https://doi.org/10.1017/CBO9781316218969

Lakoff, G. (2014). The ALL NEW Don't Think of an Elephant!: Know Your Values and Frame the Debate. White River Junction, Vermont: Chelsea Green Publishing.

Luntz, F. (2007). Words That Work: It's Not What You Say, It's What People Hear. New York: Hyperion.

Mayweg-Paus, E., \& Jucks, R. (2018). Conflicting Evidence or Conflicting Opinions? Two-Sided Expert Discussions Contribute to Experts' Trustworthiness. Journal of Language and Social Psychology, 37(2), 203-223. https://doi. org/10.1177/0261927X17716102

Ostin, J.L. (1962). Sense and Sensibilia. In G.J. Warnock (Ed.). Oxford: Clarendon Press.

Ovchinnikova, I. (2018). Effect of the Content Complexity on Hesitations in Adolescents' Narratives. Psychology of Language and Communication, 22(1), 1-20. https://doi.org/10.2478/plc-2018-0001

Searle, J.R. (1998). Mind, Language and Society: Philosophy in the Real World. New York: Basic Books. 
Мас-медійні особливості побудови ефективного наративу...

Sillanpää, A. (2015). Strategic Communications and Need for Societal Narratives. Paper presented at the The Riga Conference 2015 (Riga, November 13, 2015). Retrieved from https://www.rigaconference.lv/rc-views/22/strategiccommunications-and-need-for-societal-narratives

Suzuki, Y. (2017). Validity of new measures of implicit knowledge: Distinguishing implicit knowledge from automatized explicit knowledge. Applied Psycholinguistics, 38(5), 1229-1261. https://doi.org/10.1017/S014271641700011X

Wardhaugh, R. (2010). An Introduction to Sociolinguistics (6 $6^{\text {nd }}$ ed.). Chichester: WileyBlackwell.

Zehfuss, M. (2002). Constructivism in International Relations: The Politics of Reality. Cambridge: Cambridge University Press. https://doi.org/10.1017/ CBO9780511491795

\section{Ресурси}

Central Intelligence Agency. (2018). Retrieved from https://www.cia.gov (07.06.2018).

I am the Guard. (2018). National Guard of the USA. Retrieved from http://www. nationalguard.mil/About-the-Guard/I-am-the-Guard (07.06.2018).

\section{References}

Ataian, E.R. (1981). Kommunikatsiia $i$ raskrytiie potentsii yazykovogo znaka [Communication and reveal of a lingual sign potentia]. Yerevan: Yerevan State University [in Russian].

Batsevich, F.S. (2004). Prolegomeny k teorii kommunikativnogo smysla [Prolegomena to the theory of communicative sense]. Kultura narodov Prochernomoria Culture of the Peoples of the Black Sea Region, 49(1), 77-79 [in Russian].

Dobrosklonskaia, T.G. (2014). Massmediynyi diskurs kak obiekt nauchnogo issledovaniia [Mass media discourse as an object of scientific description]. Nauchnyie vedomosti Bielgorodskogo gosudarstvennogo universiteta Scientific Journal of Bielgorod State University, 13(184), Issue 22, 181-187 [in Russian].

Karasik, V.I. (2002). Yazykovoi krug: lichnost, kontsepty, diskurs [Language circle: identity, concepts, discourse]. Volgograd: Peremena [in Russian].

Kompantseva, L.F. (2018). Psykholinhvistychnyi opys tekhnolohichnoho dyskursu novykh media [Psychological and linguistic description of technology discourse of new media]. Psykholinhvistyka - Psycholinguistics, 23(2), 120-131. http://doi. org/10.5281/zenodo.1208639 [in Ukrainian].

Kubriakova, Ye.S. (2004). Ob ustanovkakh kognitivnoi nauki i aktualnykh problemakh kognitivnoi lingvistiki [About foundations of cognitive science and topical problems of congnitive linguistics]. Voprosy kognitivnoi lingvistiki - Issues of Cognitive Linguistics, 1, 6-17 [in Russian].

Makarov, M.L. (2003). Osnovy teorii discursa [Basics of discourse theory]. Moscow: ITDGK Gnosis [in Russian].

Pocheptsov, G.G. (2013). Izbrannyie trudy po lingvistike [Selected papers on linguistics]. Vinnytsia: Nova knyha [in Russian]. 
Pocheptsov, H.H. (2017a). Mediasoznaniie: kak naiti chernuiu koshku v tiomnoi komnate [Media Consciousness: How to find a black cat in a dark room]. RELGA - RELGA, 12(330). Retrieved from http://www.relga.ru/Environ/ WebObjects/tgu-www.woa/wa/Main?textid=5147\&level $1=$ main\&level2 $=$ articles (07.05.2019) [in Russian].

Pocheptsov, H.H. (2017b). Doktor filolohichnyh nauk Heorhii Pocheptsov: «Duzhe vazhlyvo zminyty naratyv «zrada» na «uzpih» [Doctor of Sciences Heorhii Pocheptsov: «It is very important to substitute the «Betrayal» narrative with the «Success» narrative»]. Uriadovyi kurier - Government Courier. 13.10.2017. Retrieved from https:/ukurier.gov.ua/uk/articles/doktor-filologichnih-nauk-georgijpochepcov-duzhe- (07.05.2019) [in Ukrainian].

Selivanova, Ye.A. (2002). Osnovy lingvisticheskoy teorii teksta $i$ kommunikatsii [Basics of the linguistic theory of text and communication]. Kyiv: Fitotsentr [in Russian].

Antoniades, A., O’Loughlin, B., \& Miskimmon, A. (2010). Great Power Politics and Strategic Narratives. Working Paper, 7, The Centre for Global Political Economy, University of Sussex. https://doi.org/10.4324/9781315770734

Bell, A. (1995). Language and the Media. Annual Review of Applied Linguistics, 15, 23-41. https://doi.org/10.1017/S0267190500002592

Bucholtz, M., \& Hall, K. (2008). All of the Above: New Coalitions in Sociocultural Linguistics. Journal of Sociolinguistics, 12(4), 401-431. https://doi.org/10.1111/ j.1467-9841.2008.00382.x

Chomsky, N. (2008). Talks at Google. Retrieved May 2, 2008. Retrieved from https:// www.youtube.com/watch? $\mathrm{v}=\mathrm{rnLWSC} 5 \mathrm{p} 1 \mathrm{XE} \# \mathrm{t}=27 \mathrm{~m} 38 \mathrm{~s}$

Clementson, D.E. (2018). Effects of Dodging Questions: How Politicians Escape Deception Detection and How They Get Caught. Journal of Language and Social Psychology, 37(1), 93-113. https://doi.org/10.1177/0261927X17706960

Collins. (2017). 2017 Word of the Year Shortlist. Retrieved from https://www. collinsdictionary.com/word-lovers-blog/new/collins-2017-word-of-the-yearshortlist,396,HCB.html

Damen, D., Wijst, P., Amelsvoort, M., \& Krahmer, E. (2018). Perspective-Taking in Referential Communication: Does Stimulated Attention to Addressees' Perspective Influence Speakers' Reference Production? Journal of Psycholinguistic Research, 48, 257-288. https://doi.org/10.1007/s10936-018-9602-7

Denzin, N.K. (1989). Interpretive Biography. Newbury Park, California, London: Sage. https://doi.org/10.4135/9781412984584

Dijk, T.A., van. (1995). On Macrostructures, Mental Models, and other Inventions: A brief personal history of the Kintsch-van Dijk theory. Discourse Comprehension: Essays in Honor of Walter Kintsch (pp. 383-410). London: Hillsdale.

Do Social Media Threaten Democracy? (2017). The Economist. Retrieved November 4. Retrieved from https://www.economist.com/news/leaders/21730871-facebookgoogle-and-twitter-were-supposed-save-politics-good-information-drove-out

Fillmore, Ch.J. (1982). Frame Semantics. Linguistics in the Morning Calm (pp. 111137). Seoul: Hanshin Publishing Co.

Genette, G. (1930). Narrative Discourse. An Essay in Method. Ithaca, New York: Cornell University Press.

Grice, H.P. (1989). Studies in the Way of Words. Harvard: Harvard University Press.

Herman, E.S., \& Chomsky, N. (1988). Manufacturing Consent: The Political Economy of the Mass Media. New York: Pantheon Books. 
Мас-медійні особливості побудови ефективного наративу...

Hopf, T. (2002). Social Construction of International Politics: Identities \& Foreign Policies. Cornell: Cornell University Press.

Holtzhausen, D., \& Zerfass, A. (2015). Strategic Communication: Opportunitities and Challenges of the Research Area. In D. Holtzhausen \& A. Zerfass (Eds.), The Routledge Handbook of Strategic Communication (pp. 3-17). New York, London: Routledge, Taylor and Francis Group. https://doi. org/10.4324/9780203094440

Kratochwil, F. (1993). The Embarrassment of Changes: Neo-Realism as the Science of Realpolitik without Politics. Review of International Studies, 19, 1-18. https:// doi.org/10.1017/S0260210500117346

Krebs, R.R. (2015). Narrative and the Making of US National Security. New York: Cambridge University Press. https://doi.org/10.1017/CBO9781316218969

Lakoff, G. (2014). The ALL NEW Don't Think of an Elephant!: Know Your Values and Frame the Debate. White River Junction, Vermont: Chelsea Green Publishing.

Luntz, F. (2007). Words That Work: It's Not What You Say, It's What People Hear. New York: Hyperion.

Mayweg-Paus, E., \& Jucks, R. (2018). Conflicting Evidence or Conflicting Opinions? Two-Sided Expert Discussions Contribute to Experts' Trustworthiness. Journal of Language and Social Psychology, 37(2), 203-223. https://doi. org/10.1177/0261927X17716102

Ostin, J.L. (1962). Sense and Sensibilia. In G.J. Warnock (Ed.). Oxford: Clarendon Press.

Ovchinnikova, I. (2018). Effect of the Content Complexity on Hesitations in Adolescents' Narratives. Psychology of Language and Communication, 22(1), 1-20. https://doi.org/10.2478/plc-2018-0001

Searle, J.R. (1998). Mind, Language and Society: Philosophy in the Real World. New York: Basic Books.

Sillanpää, A. (2015). Strategic Communications and Need for Societal Narratives. Paper presented at the The Riga Conference 2015 (Riga, November 13, 2015). Retrieved from https://www.rigaconference.lv/rc-views/22/strategiccommunications-and-need-for-societal-narratives

Suzuki, Y. (2017). Validity of new measures of implicit knowledge: Distinguishing implicit knowledge from automatized explicit knowledge. Applied Psycholinguistics, 38(5), 1229-1261. https://doi.org/10.1017/ S014271641700011X

Wardhaugh, R. (2010). An Introduction to Sociolinguistics (6 $6^{\text {nd }}$ ed.). Chichester: WileyBlackwell.

Zehfuss, M. (2002). Constructivism in International Relations: The Politics of Reality. Cambridge: Cambridge University Press. https://doi.org/10.1017/ CBO9780511491795

\section{Resources}

Central Intelligence Agency. (2018). Retrieved from https://www.cia.gov (07.06.2018). I am the Guard. (2018). National Guard of the USA. Retrieved from http://www. nationalguard.mil/About-the-Guard/I-am-the-Guard (07.06.2018). 


\begin{abstract}
АНОТАЦІЯ
Мета дослідження - визначити принципи побудови ефективних наративів із використанням можливостей стратегічних комунікацій та мас-медіа.

Методики дослідження. Публікації в сучасних англомовних та українських мас-медіа аналізувалися з використанням методів і прийомів дискурс-аналізу, контент- та інтент-аналізу з елементами прагматичного та наративного аналізу. Авторською методикою передбачено вияв авторського задуму та мотивів, основних топосів та точки фокусування наративу, встановлення прихованих переконань, соціальної та психологічної зумовленості сприйняття адресатом наративу, окреслення ефективних стратегій побудови та поширення наративу в мас-медіа.
\end{abstract}

Результати дослідження. Сучасні мас-медіа у цілому здатні формувати бажані фрейми в свідомості аудиторії та створювати ментальну модель ситуації, на яку покладається адресат. Наразі, прийняття рішень залежить від медіасвідомості, тобто віртуального світу, нав'язаного мас-медіа й побудованого за допомогою відповідних наративів. Сучасні стратегічні наративи зазвичай мають зовнішнє фокусування, яке забезпечує більшу довіру в разі підтримки та подання знаменитостями й експертами. Конкуруючі наративи, а також безліч можливих інтерпретацій подій, знищуються за допомогою мас-медіа, які починають транслювати одну інтерпретацію події, що відповідає наративу, таким чином, це стає істиною. Одночасне використання різних мас-медіа підсилює вплив і підтримує наратив. Періодична інформація змінює свій статус і стає не тільки фактом, а й загальним знанням. Наратив є не тільки розповіддю про обрані події, а й переконанням за своєю природою. Переконання посилюється, якщо наративи резонують із системою цінностей адресата.

Висновки. Як інструмент стратегічних комунікацій ефективний наратив будується з урахуванням усіх аспектів комунікації, серед яких особливого значення набувають психолінгвістичний та соціальний. Подальше розуміння проблеми формування наративів дозволить систематизувати передовий досвід і ключові елементи наративів для розробки актуальних наративів, зокрема іміджеформувального характеру.

Ключові слова: стратегічні комунікачії, наратив, медіа-свідомість, фрейм, мac-медіa.

Лисичкина Ирина. Масс-медийные особенности построения эффективного нарратива как инструмента стратегических коммуникаций

\title{
АННОТАЦИЯ
}

Цель исследования - определить принципы построения эфрфективных нарративов с использованием возможностей стратегических коммуникаций и средств массовой информации.

Методики исследования. Публикации в современных англоязычных и украинских СМИ анализировались с использованием методов и приёмов дискурс- 
Мас-медійні особливості побудови ефективного наративу...

анализа, контент- и интент-анализа с элементами прагматического и нарративного анализа. Авторской методикой было предусмотрено выявление авторского замысла и мотивов, основных топосов и точки фокусировки нарратива, определение скрытых убеждений, социальной и психологической обусловленности восприятия адресатом нарратива, выявление эффективных стратегий построения и распространения нарратива в СМИ.

Результаты исследования. Современные СМИ в целом способны фрормировать желаемые фреймы в сознании аудитории, создавая ментальную модель ситуации, на которую полагается адресат. Принятие решений в настоящее время зависит от медиа-сознания, т.е. виртуального мира, навязанного СМИ и построенного с помощью соответствующих нарративов. Современные стратегические нарративы обычно имеют внешнюю фокусировку, обеспечивающую больще доверия в случае поддержки и представления знаменитостями и экспертами. Конкурирующие нарративы, а также множество возможных интерпретаций событий уничтожаются с помощью СМИ, которые начинают транслировать одну интерпретацию события, соответствующую нарративу, тем самым делая его правдой. Одновременное использование нескольких различных СМИ усиливает влияние и поддерживает нарратив. Повторяющаяся информация изменяет свой статус и становится не только фрактом, но и общим знанием. Любой нарратив - это не только повествование о выбранных событиях, но и убеждение по своей сути. Убеждение усиливается, если нарративы резонируют с системой ценностей aдpecama.

Выводы. Как инструмент стратегических коммуникаций эффрективный нарратив строится с учетом всех аспектов коммуникации, среди которых особое значение приобретают психолингвистический и социальный. Дальнейшее понимание проблемы формирования нарративов позволит систематизировать передовой опыт и ключевые элементы нарративов для разработки аактуальных нарративов, а именно имиджеформирующих нарративов.

Ключевые слова: стратегчческие коммуникации, нарратив, медиа-сознание, фрейм, средства массовой информации. 